\title{
Erratum to: Pelvic Organ Prolapse/Urinary Incontinence Sexual Questionnaire (PISQ-12): psychometric validation of the Iranian version
}

\author{
Zohreh Momenimovahed • Minoo Pakgohar • Ali Montazeri
}

Published online: 3 December 2014

(C) The International Urogynecological Association 2014

\section{Erratum to: Int Urogynecol J}

DOI 10.1007/s00192-014-2520-9

The authors' names were rendered wrongly in the original publication. Their correct names are: Zohreh Momenimovahed, Minoo Pakgohar, and Ali Montazerifamily names underlined.

The online version of the original article can be found at http://dx.doi.org/ 10.1007/s00192-014-2520-9.

Z. Momenimovahed

Department of Reproductive Health, School of Nursing and

Midwifery, Tehran University of Medical Sciences, Tehran, Iran

e-mail: momeni.z@gmail.com

M. Pakgohar $(\triangle)$

Department of Geriatric nursing, Reproductive Health, School of

Nursing and Midwifery, Tehran University of Medical Sciences,

Tohid Sq., Nosrat St, Tehran, Iran

e-mail: mpakgohar@razi.tums.ac.ir

\section{A. Montazeri}

Mental Health Research Group, Health Metrics Research Centre, Iranian Institute for Health Sciences Research, ACECR, Tehran, Iran

e-mail: montazeri@acecr.ac.ir 